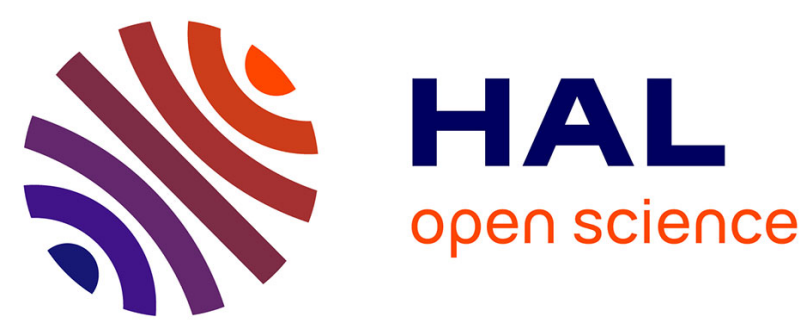

\title{
Non-enzymatic lipid mediators, neuroprostanes, exert the antiarrhythmic properties of docosahexaenoic acid
} Jérôme Roy, Camille Oger, Jérôme Thireau, Julien Roussel, Olivia Mercier-Touzet, Delinger Faure, Edith Pinot, Charlotte Farah, Douglass Taber, Jean-Paul Cristol, et al.

\section{To cite this version:}

Jérôme Roy, Camille Oger, Jérôme Thireau, Julien Roussel, Olivia Mercier-Touzet, et al.. Non-enzymatic lipid mediators, neuroprostanes, exert the antiarrhythmic properties of docosahexaenoic acid. Free Radical Biology and Medicine, 2015, 86, pp.269 - 278. 10.1016/j.freeradbiomed.2015.04.014 . hal-01753886

\section{HAL Id: hal-01753886 \\ https://hal.umontpellier.fr/hal-01753886}

Submitted on 8 Nov 2018

HAL is a multi-disciplinary open access archive for the deposit and dissemination of scientific research documents, whether they are published or not. The documents may come from teaching and research institutions in France or abroad, or from public or private research centers.
L'archive ouverte pluridisciplinaire HAL, est destinée au dépôt et à la diffusion de documents scientifiques de niveau recherche, publiés ou non, émanant des établissements d'enseignement et de recherche français ou étrangers, des laboratoires publics ou privés.

\section{(c)(1)}

Distributed under a Creative Commons Attribution| 4.0 International License 


\title{
Nonenzymatic lipid mediators, neuroprostanes, exert the antiarrhythmic properties of docosahexaenoic acid
}

\author{
Jérôme Roy ${ }^{\mathrm{a}}$, Camille Oger $^{\mathrm{b}}$, Jérôme Thireau ${ }^{\mathrm{a}}$, Julien Roussel ${ }^{\mathrm{a}}$, Olivia Mercier-Touzet ${ }^{\mathrm{a}}$, \\ Delinger Faure $^{\mathrm{a}, \mathrm{b}}$, Edith Pinot ${ }^{\mathrm{b}}$, Charlotte Farah ${ }^{\mathrm{a}}$, Douglass F. Taber ${ }^{\mathrm{c}}$, Jean-Paul Cristol ${ }^{\mathrm{a}}$, Jetty C.Y. Lee \\ , Alain Lacampagne ${ }^{\mathrm{a}}$, Jean-Marie Galano ${ }^{\mathrm{b}, 1}$, Thierry Durand ${ }^{\mathrm{b}, 1}$, \\ Jean-Yves Le Guennec a,*,1 \\ a INSERM U1046-UMR 9214, Centre National de la Recherche Scientifique, Physiologie et Médecine Expérimentale du Coeur et des Muscles, \\ Université de Montpellier, 34295 Montpellier Cedex 5, France \\ ${ }^{\mathrm{b}}$ Institut des Biomolécules Max Mousseron, UMR 5247, Centre National de la Recherche Scientifique, Université de Montpellier, ENSCM, Montpellier, France ${ }^{\mathrm{c}}$ Department of \\ Chemistry and Biochemistry, University of Delaware, Newark, DE 19716, USA \\ ${ }^{\mathrm{d}}$ School of Biological Sciences, The University of Hong Kong, Hong Kong, SAR
}

Oxidative stress Neuroprostanes Antiarrhythmic Cardioprotection DHA

Ryanodine receptor

Calcium

Free radicals

\begin{abstract}
Neuroprostanes are lipid mediators produced by nonenzymatic free radical peroxidation of docosahexaenoic acid (DHA). DHA is associated with a lower atherosclerosis risk, suggesting a beneficial role in cardiovascular diseases. The aim of this study was to investigate the influence of DHA peroxidation on its potentially antiarrhythmic properties (AAP) in isolated ventricular cardiomyocytes and in vivo in postmyocardial infarcted mice. Calcium imaging and biochemical experiments indicate that cardiac arrhythmias induced by isoproterenol are associated with $\mathrm{Ca}^{2+}$ leak from the sarcoplasmic reticulum after oxidation and phosphorylation of the type 2 ryanodine receptor (RyR2) leading to dissociation of the FKBP12.6/RyR2 complex. Both oxidized DHA and 4(RS)-4-F $4 \mathrm{t}-$ NeuroP prevented cellular arrhythmias and posttranslational modifications of the RyR2 leading to a stabilized FKBP12.6/RyR2 complex. DHA per se did not have AAP. The AAP of $4(R S)-4-\mathrm{F}_{4 \mathrm{t}}-\mathrm{NeuroP}$ was also observed in vivo. In this study, we challenged the paradigm that spontaneously formed oxygenated metabolites of lipids are undesirable as they are unconditionally toxic. This study reveals that the lipid mediator $4(R S)-4-\mathrm{F}_{4 \mathrm{t}}-$ neuroprostane derived from nonenzymatic peroxidation of docosahexaenoic acid can counteract such deleterious effects through cardiac antiarrhythmic properties. Our findings demonstrate $4(R S)-4-\mathrm{F}_{4 \mathrm{t}}-\mathrm{NeuroP}$ as a mediator of the cardioprotective AAP of DHA. This discovery opens new perspectives for products of nonenzymatic oxidized $\omega 3$ polyunsaturated fatty acids as potent mediators in diseases that involve ryanodine complex destabilization such as ischemic events.
\end{abstract}

The cardioprotective effects of $\omega 3$ polyunsaturated fatty acids ( $\omega 3$ PUFAs $)^{2}$ have been evident since the mid-1970 s [1]. The intake of fatty fish such as mackerel or tuna is associated with a lower risk of cardiac arrhythmias, including sudden cardiac death (SCD) [2-4] and

\footnotetext{
Abbreviations: 4(RS)-4- $\mathrm{F}_{4 \mathrm{t}}-\mathrm{NeuroP}, 4(R S)-4-\mathrm{F}_{4 \mathrm{t}}-$ neuroprostane; $\omega 3$ PUFA, $\omega 3$ polyunsaturated fatty acid; AAP, antiarrhythmic properties; COX-2, cyclooxygenase; CYP450, cytochrome P450; DHA, docosahexaenoic acid; DNP, carbonylated RyR; ECG, electrocardiograms; EF, ejection fraction; ES, extrasystoles; F, fluorescence; GPx, glutathione peroxidase enzymes; HR, heart rate; Iso, isoproterenol; LOX, lipoxygenase; LV, left ventricular; NE, norepinephrine; PMI, post-myocardial infarcted; ROS, reactive oxygen specie; RyR2, type 2 ryanodine receptor; SCD, sudden cardiac death; sHE, epoxide hydrolase (diols); SR, sarcoplasmic reticulum; Vit E, vitamin E

* Corresponding author. Fax: +33467415242.

E-mail address: Jean-Yves.Le-Guennec@Inserm.Fr (J.-Y. Le Guennec).

${ }^{1}$ These authors contributed equally to this work.
}

arrhythmic coronary heart disease death [5]. Administration of Omacor, a mixture of $850 \mathrm{mg}$ of eicosapentaenoic acid and docosahexaenoic acid (DHA), the two major PUFAs of fatty fish, decreased the incidence of SCD in secondary prevention of myocardial infarction [6]. The mechanisms responsible for the antiarrhythmic properties (AAP) of PUFAs remain unclear. In dogs, infusion of a DHA emulsion tended to slow heart rate (HR), shortened the corrected QT interval at rest, and significantly prevented ischemia-induced fatal ventricular arrhythmias [7]. These experiments confirmed previous reports on the prevention of ischemia-induced ventricular arrhythmias in dogs [8] and marmosets [9] by PUFAs. In humans, a significant slowing of HR and the likelihood of prolonged QT has been observed [10].

Experimental studies on isolated cardiac cells suggest that $\omega 3$ PUFAs have direct cardiac electrophysiological effects [11]. However, DHA is highly prone to peroxidation and we have shown that nonenzymatic oxygenated products of DHA and not DHA per se 
are active on cardiac ionic channels [12]. In agreement, it has been demonstrated in rabbit ventricular cells that early depolarization induced by $\mathrm{H}_{2} \mathrm{O}_{2}$ is inhibited by DHA, whereas reactive oxygen species (ROS) production is not altered, indicating the resiliency of oxidized DHA [13].

DHA can be oxidized through two pathways: enzymatically, resulting in the production of compounds such as resolvins or maresins, or nonenzymatically by ROS initiation and propagation of free radical reactions, leading to the release of numerous products, including neuroprostanes ( $\mathrm{F}_{4}$-NeuroP's) [14]. Neuroprostanes are recognized as oxidative stress biomarkers for the DHArich brain and are associated with ischemic stroke and neurodegenerative diseases $[15,16]$. More recently, it has been proposed that $\mathrm{F}_{4}$-NeuroP's may play a favorable role as potential bioactive components in identifying atherosclerosis risk [17].

In the present study, we show through in cellulo and in vivo approaches that nonenzymatic oxidation of DHA is a prerequisite for obtaining ventricular antiarrhythmic effects. In particular, one of the $\mathrm{F}_{4}$-NeuroP isomers, $4(R S)-4-\mathrm{F}_{4 \mathrm{t}}$-neuroprostane $\left(4(R S)-4-\mathrm{F}_{4 \mathrm{t}^{-}}\right.$ NeuroP), seems to be the main antiarrhythmic metabolite of DHA in preventing deleterious posttranslational modification of RyR2 and thus regulating calcium homeostasis.

\section{Materials and methods}

\section{Animal experiments}

Male $\mathrm{C} 57 \mathrm{Bl} / 6$ mice (Janvier, France) 7 weeks of age were randomly assigned into two main groups: (1) mice with postmyocardial infarction (PMI mice) after left coronary artery ligation as previously described [18] and (2) sham-operated mice that were submitted to the surgical procedure but not to the artery ligation. All animal-handling procedures conformed to European Parliament Directive 2010/63/EU and the institutional Animal Research Committee Council on the Protection of Animals (CEEALR-12096).

In brief, anesthesia was performed for left thoracotomy and cardiac monitoring ( $2 \%$ isoflurane $/ \mathrm{O}_{2}$, Aerrane, Baxter, France). The artery was ligated 1-2 $\mathrm{mm}$ beyond the emergence from the top of the left atrium, using an 8-0 suture for PMI mice. A subcutaneous injection of $0.01 \mathrm{ml}$ buprenorphine solution $(0.3 \mathrm{mg} / \mathrm{ml})$ for postoperative analgesia was administered. Shams were subjected to the same surgical procedure but without coronary artery ligation. The mice were housed in single cages in a room under regulated temperature and hygroscopic conditions $\left(23 \pm 1{ }^{\circ} \mathrm{C}, 45 \pm 10 \%\right.$ humidity, light-dark schedule of $12 \mathrm{~h}: 12 \mathrm{~h}$ ad libitum feed).

After 4 weeks, the mice were randomly assigned to the treatment groups: sham and PMI dosed with vehicle ( $\mathrm{NaCl} 0.9 \%)$, PMI mice treated with $10 \mu \mathrm{M}$ DHA (PMI DHA), PMI treated with $10 \mu \mathrm{M}$ DHA and $1 \mu \mathrm{M} \alpha$-tocopherol (PMI DHA + Vit E), PMI mice treated with $10 \mu \mathrm{M}$ DHA and $1 \mu \mathrm{M}$ hydrogen peroxide (PMI DHA $\left.+\mathrm{H}_{2} \mathrm{O}_{2}\right)$, and PMI mice treated with $1 \mu \mathrm{M} 4(R S)-4-\mathrm{F}_{4 \mathrm{t}} \mathrm{NeuroP}$. We chose to work on PMI mice challenged with norepinephrine (NE) because it has been shown that the AAP of DHA is secondary to myocardial infarction in human [6].

Treatments were administered as intravenous injections $(200 \mu \mathrm{l})$ of the prepared solution equivalent to 10 times the concentration to reach the final concentrations matching in cellulo experiments.

It is known that the activation of the adrenergic nervous system is one factor that may play a crucial role in the genesis of arrhythmias associated with acute myocardial infarction [19]. To mimic this activation, all PMI mice were then challenged intraperitoneally (ip) with the $\beta 1$-adrenergic agonist norepinephrine $(2.5 \mathrm{mg} / \mathrm{kg}$ ) [20] $20 \mathrm{~min}$ after they received their treatment.

\section{Echocardiography}

Doppler echocardiography was performed using a highresolution ultrasound system (Vevo 2100; VisualSonics, Toronto, ON, Canada) equipped with a $40-\mathrm{MHz}$ transducer. The mice were anesthetized with $1.5 \%$ isoflurane in $100 \%$ oxygen and placed on a heating table in a supine position. Body temperature was monitored through a rectal thermometer and maintained at $36-38{ }^{\circ} \mathrm{C}$, and electrocardiograms (ECGs) were recorded all along the echocardiographic procedure with limb electrodes. Ejection (EF) and shortening fractions were calculated from the left-ventricular diameters on M-mode measurements at the level of papillary muscles in a parasternal short-axis two-dimensional view. To better consider coronary ligation-induced left-ventricular remodeling, EF was also calculated from a B-mode parasternal long-axis view by tracing endocardial end-diastolic and end-systolic areas to estimate left-ventricular volumes, and the endocardial fractional area change on a parasternal short-axis view at papillary muscle level was calculated. Pulsed-wave Doppler of the ascending aortic blood flow was recorded, permitting measurement of the velocity time integral. All measurements were quantified and averaged for three cardiac cycles (Table 1 ).

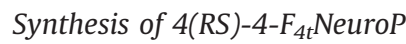

Using the protocol previously reported, we synthesized $6 \mathrm{~F}_{4}$ NeuroP's. The strategy was based on an easily accessible bicyclic precursor to obtain isoprostanoid derivatives [21], whereas a more refined strategy was used for the synthesis of the isomers, $4(R S)-4-\mathrm{F}_{4 \mathrm{t}}$ NeuroP [22], 10- $\mathrm{F}_{4 \mathrm{t}}$-NeuroP [23], and 14 $(R S)-14-\mathrm{F}_{4 \mathrm{t}} \mathrm{-NeuroP}$ (unpublished data). The $13-\mathrm{F}_{4 \mathrm{t}}-\mathrm{NeuroP}$ was synthesized using another strategy [24].

\section{Fatty acid solution and oxidation}

To observe antioxidant or oxidant effects, cells were incubated 20 min in Tyrode solution containing $10 \mu \mathrm{M}$ DHA or $10 \mu \mathrm{M}$ DHA + $1 \mu \mathrm{M}$ Vit E or $10 \mu \mathrm{M}$ DHA $+1 \mu \mathrm{M} \mathrm{H}_{2} \mathrm{O}_{2}$. To prepare these solutions, DHA (stock prepared in ethanol) was added to the Tyrode solution after Vit $\mathrm{E}$ (stock prepared in chloroform) or $\mathrm{H}_{2} \mathrm{O}_{2}$ (stock prepared in reverse-osmosis water). The stock solution of $4(R S)-4-\mathrm{F}_{4 \mathrm{t}} \mathrm{NeuroP}$ was prepared in Tyrode solution and diluted accordingly for the experimentations.

\section{Quantification of 4(RS)-4- $F_{4 t}$ NeuroP}

In Tyrode solution (control), $10 \mu \mathrm{M}$ DHA was incubated with or without $1 \mu \mathrm{M} \alpha$-tocopherol (Vit E) or $1 \mu \mathrm{M} \mathrm{H}_{2} \mathrm{O}_{2}$ for 20 min at room temperature. The reaction was terminated with the antioxidant butylated hydroxytoluene $(0.005 \%, \mathrm{w} / \mathrm{v})$. The internal standard $\mathrm{C} 21$ $15-\mathrm{F}_{2 \mathrm{t}}$-IsoP (2.5 ng), synthesized by IBMM (Montpellier, France), was

Table 1

Echocardiographic parameters in sham and infarcted mice.

\begin{tabular}{lcc}
\hline Parameter & Sham $(n=6)$ & PMI $(n=9)$ \\
\hline HR (bpm) & $427 \pm 29$ & $454 \pm 37$ \\
EF (\%) & $60 \pm 4$ & $25 \pm 12^{*}$ \\
FS (\%) & $32 \pm 3$ & $12 \pm 6^{*}$ \\
FAC (\%) & $52 \pm 3$ & $19 \pm 9^{*}$ \\
EF (\%) B-mode & $58 \pm 5$ & $12 \pm 7^{*}$ \\
AoVTI (mm) & $49.0 \pm 5.8$ & $35.6 \pm 4.0^{*}$ \\
\hline
\end{tabular}

HR, heart rate; EF, ejection fraction; FS, fractional shortening; FAC, fractional area change; AoVTI, aortic velocity time integral. Data are represented as the mean \pm SD.

$* p<0.001$ for sham vs PMI. 
added to each sample mix. The sample was further diluted in aqueous sodium acetate solution ( $\mathrm{pH} 4.6$ ), acidified with $1 \mathrm{M} \mathrm{HCl}$, and applied to a prewashed (methanol) Bond Elut Certify II SPE cartridge (Agilent, Santa Clara, CA USA). After the sample was loaded (control, DHA, or $\mathrm{DHA}+$ Vit E or DHA $+\mathrm{H}_{2} \mathrm{O}_{2}$ ), it was sequentially cleaned with water/ methanol (1/1) and hexane/ethyl acetate (7/3) and then the $F_{4}$-NeuroP's were eluted with ethyl acetate/methanol (9/1). The eluate was dried under nitrogen and then derivatized at room temperature for 30 min with $10 \%$ pentafluorobenzyl bromide and 10\% N,N-diisopropylethylamine prepared in acetonitrile $(2 / 1)$. Thereafter, it was dried under nitrogen and then derivatized with $\mathrm{N}, \mathrm{O}$-bis(trimethylsilyl) trifluoroacetamide + trimethylsilylchlorosilane $1 \%$ and $\mathrm{N}, \mathrm{N}$-dimethylformamide (2:1) (Sigma-Aldrich, St. Louis, MO, USA). After the reagents were dried under nitrogen, the samples were resuspended in decane.

Gas chromatography-mass spectrometry set at negative ion chemical ionization (NICI; TraceGC and DSQ II mass spectrometer, Thermo Fisher Scientific, Waltham, MA, USA) was used to determine 4(RS)-4$\mathrm{F}_{4 \mathrm{t}}$-NeuroP [25]. An analytical column (FactorFour; Varian, Palo Alto, CA, USA)-fused silica capillary was used. Helium gas was the carrier gas and the column temperature was programmed from 140 to $250^{\circ} \mathrm{C}$ at $30{ }^{\circ} \mathrm{C}$ per minute and then 250 to $300{ }^{\circ} \mathrm{C}$ at $4{ }^{\circ} \mathrm{C}$ per minute and remained at this temperature for $10 \mathrm{~min}$. The ion source temperature was $200{ }^{\circ} \mathrm{C}$ and isobutane $(1 \mathrm{ml} / \mathrm{min})$ was used as the reagent gas for $\mathrm{NICl}$. Selected ion monitoring was performed to monitor ions at $\mathrm{m} / \mathrm{z}$ 593.5 for $4(R S)-4-\mathrm{F}_{4 \mathrm{t}} \mathrm{NeuroP}$ and at $\mathrm{m} / z 583.5$ for $\mathrm{C} 21-15-\mathrm{F}_{2 \mathrm{t}}-\mathrm{IsoP}$ internal standard. Quantitation was achieved by relating the peak area of the $4(R S)-4-\mathrm{F}_{4 \mathrm{t}} \mathrm{NeuroP}$ to the $\mathrm{C} 21-15-\mathrm{F}_{2 \mathrm{t}}-\mathrm{IsoP}$ internal standard peak.

\section{Preparation of cardiomyocytes}

Cellular experiments were performed on freshly isolated leftventricular myocytes from the noninfarcted free wall (excluding the border zone). In brief, after cervical dislocation, the heart was removed and washed and the aorta was cannulated to a modified Langendorff system. The heart was perfused at a retrograde flow rate of $5-10 \mathrm{ml} / \mathrm{min}$ at $37{ }^{\circ} \mathrm{C}$ for $6-8$ min with a modified Tyrode solution composed of $113 \mathrm{mM} \mathrm{NaCl}, 4.7 \mathrm{mM} \mathrm{KCl}, 0.6 \mathrm{mM} \mathrm{KH}_{2} \mathrm{PO}_{4}$, $0.6 \mathrm{mM} \mathrm{Na}_{2} \mathrm{HPO}_{4}, 1.2 \mathrm{mM} \mathrm{MgSO}_{4}, 12 \mathrm{mM} \mathrm{NaHCO}, 10 \mathrm{mM} \mathrm{KHCO}$, $10 \mathrm{mM}$ Hepes ( $\mathrm{pH} 7.4$ ), and $0.1 \mathrm{~g} / \mathrm{ml}$ liberase dispase (high research grade; Roche, Basel, Switzerland).

After enzymatic treatment (4-6 min), a part of the left ventricle was removed and minced to separate the cells. Isolated myocytes were resuspended in a sterile enzyme-free Tyrode solution, and the $\mathrm{Ca}^{2+}$ concentration of the ventricular cell suspension was gradually increased to $1 \mathrm{mM}$ by the addition of $\mathrm{CaCl}_{2}$ in four sequential steps of $100,100,300$, and $500 \mu \mathrm{M}$ with a $10-\mathrm{min}$ interval between steps. Finally the cardiomyocytes were kept at room temperature $\left(22-24^{\circ} \mathrm{C}\right)$ until use. Before the treatments, the freshly isolated cardiomyocytes were superfused with standard Tyrode solution ( $121 \mathrm{mM} \mathrm{NaCl}, 5.0 \mathrm{mM} \mathrm{KCl}, 1.8 \mathrm{mM} \mathrm{CaCl}_{2}, 0.5 \mathrm{mM}$ $\mathrm{MgCl}_{2}, 0.4 \mathrm{mM} \mathrm{NaH} \mathrm{PO}_{4}, 24 \mathrm{mM} \mathrm{NaHCO}, 0.1 \mathrm{mM}$ EDTA, and $5.5 \mathrm{mM}$ glucose). Cardiomyocytes with obvious sarcolemmal blebs or spontaneous contractions were not used. Only cardiomyocytes with clear edges were selected and were used within 1-6 h of isolation.

\section{Inhibition of enzymatic lipid peroxidation of cardiomyocytes}

Inhibitors of enzymatic lipid peroxidation, anti-lipoxygenase ( 1 $\mu \mathrm{M}$ zileuton), anti-cytochrome P450 (3 $\mu \mathrm{M}$ ketoconazole), and anti-cyclooxygenase 2 ( $1 \mu \mathrm{M}$ celecoxib), from Sigma-Aldrich, and anti-epoxide hydrolase (10 nM), from Cayman Chemicals, and a combination of four inhibitors were tested with and without $10 \mu \mathrm{M}$ DHA $+1 \mu \mathrm{M} \mathrm{H}_{2} \mathrm{O}_{2}$ in the cellular arrhythmias. We also used glutathione peroxidase (GPx), which reduces lipid peroxides to alcohols and $\mathrm{H}_{2} \mathrm{O}_{2}$. A stock solution of GPx was dissolved in water with $10 \mathrm{mM}$ phosphate sodium and $1 \mathrm{mM}$ dithiothreitol. GPx was added either before the DHA $+\mathrm{H}_{2} \mathrm{O}_{2}$ mix at a concentration of 10 units ( 1 unit oxide per $1 \mu \mathrm{M}$ DHA per minute) in Tyrode solution or after the DHA $+\mathrm{H}_{2} \mathrm{O}_{2}$ mix. For all the experiments, solutions were prepared fresh from the stock and diluted with Tyrode medium.

\section{Calcium channeling}

The effects of oxidation of $\omega 3$ PUFAs on cell shortening and $\mathrm{Ca}^{2+}$ transients of field-stimulated cardiomyocytes were monitored online using a commercial myocyte calcium and contractility monitoring system (IonOptix, Milton, MA, USA) connected to a standard inverted fluorescence microscope. Cells were fieldstimulated with 1-ms current pulses delivered via two platinum electrodes. To monitor intracellular $\mathrm{Ca}^{2+}$ concentration, cardiomyocytes were loaded with the fluorescent ratiometric $\mathrm{Ca}^{2+}$ indicator Indo-1 AM ( $2 \mu \mathrm{M}$, Invitrogen, Grand Island, NY, USA). They were simultaneously illuminated at $365 \mathrm{~nm}$ using a xenon arc bulb light. Cytosolic $\mathrm{Ca}^{2+}$ concentration was determined by Indo-1 AM fluorescence, which emits at $405 \mathrm{~nm}$ and $480 \mathrm{~nm}$ concurrently. The ratio of $405 \mathrm{~nm} / 480 \mathrm{~nm}$ indicates the cytosolic $\mathrm{Ca}^{2+}$ concentration.

To observe arrhythmias (ventricular extrasystoles), the cells were bathed with $10 \mathrm{nM}$ isoproterenol and stimulated with a 30-s pacing period $(1.0 \mathrm{~Hz})$, followed by a $30-\mathrm{s}$ rest period [20,26]. Confocal imaging was performed using a Zeiss LSM510 confocal microscope (Carl Zeiss, Oberkochen, Germany) equipped with an argon laser (488 nm) and a $60 \times, 1.3$ NA oil immersion objective set at axial and radial resolutions of 1.0 and $0.4 \mu \mathrm{m}$, respectively.

$\mathrm{Ca}^{2+}$ sparks were recorded in quiescent myocytes incubated with the $\mathrm{Ca}^{2+}$ indicator Fluo-4-AM $(4 \mu \mathrm{M})$ (Molecular Probes, Eugene, OR, USA) for $15 \mathrm{~min}$. The dye was excited at $488 \mathrm{~nm}$ and the fluorescence emission was collected through a 505-nm longpass filter. Myocytes were field-stimulated at $1 \mathrm{~Hz}$ with 1 -ms current pulses delivered via two platinum electrodes, one on each side of the perfusion chamber. During the rest period that followed stimulation, myocytes were repetitively scanned along the entire length of the cell at 1.5-ms intervals, for a maximum of $6 \mathrm{~s}$. The laser intensity was reduced to $5 \%$ maximum to decrease cell damage and dye bleaching. Line scan diagrams were constructed by stacking emission lines, corresponding to excitation scans, in temporal order. An average of the $\mathrm{Ca}^{2+}$ sparks was determined by the intensity of each sequential scan line and plotting the mean intensity as a function of time. The SparkMaster plug-in for Image software was used to detect and analyze $\mathrm{Ca}^{2+}$ sparks.

\section{Immunoblot}

Proteins were extracted from frozen basal left-ventricular cells (50 mg) homogenized with a manual Polytron instrument. Cells were then lysed in $600 \mu$ lextraction buffer (Tris maleate $10 \mathrm{mM}$, $\mathrm{NaF} 35 \mathrm{mM}$, Triton $1 \%$, activated orthovanadate $20 \mathrm{mM}$, inhibitor cocktail; Roche) for 45 min under rotating agitation. Membrane and cytosolic proteins were collected from the supernatant after 5 min centrifugation at $10,000 \mathrm{~g}$ at $4{ }^{\circ} \mathrm{C}$.

For the immunoprecipitation assay, left-ventricular (LV) tissues were lysed in $1 \mathrm{ml}$ buffer containing $10 \mathrm{mM}$ Tris maleate ( $\mathrm{pH} \mathrm{6.8),}$ $35 \mathrm{mM}$ NaF, Triton 1\%, and protease inhibitors (Roche 11873580001). A concentration of $10 \mu \mathrm{g}$ anti-RyR2 antibody was used to immunoprecipitate RyR2 from $500 \mu \mathrm{g}$ of LV homogenate. The samples were incubated with anti-RyR antibody in $0.5 \mathrm{ml}$ modified RIPA buffer (Tris-HCl 10 mM, pH 7.4, NaCl 150 mM, Triton 1\%, NaF 5 mM, and 
protease inhibitor cocktail) for $2 \mathrm{~h}$ at $4{ }^{\circ} \mathrm{C}$. The immune complexes were incubated with protein A/G magnetic beads (Pierce 88802, Rockford, IL, USA) at $4{ }^{\circ} \mathrm{C}$ for $2 \mathrm{~h}$, after which the beads were washed three times with RIPA buffer.

To detect RyR2 protein oxidation, the immune complex was treated with 2,4-dinitrophenylhydrazine and the DNP-derivatized protein samples formed were detected using an Immunoblot Protein Oxidation Detection Kit (Millipore S7150, Billerica, MA, USA). Proteins were then separated using SDS-PAGE, blotted onto nitrocellulose membranes $(0.2 \mu \mathrm{m}$; GE Healthcare, Chalfont St Giles, UK), and incubated overnight at $4{ }^{\circ} \mathrm{C}$ with primary antibodies: anti-RyR2 (1/1000 dilution; Pierce) and antiFKBP12.6 (1/1000 dilution; R\&D Systems AF 4174, Minneapolis, MN, USA). Protein levels were expressed relative to glyceraldehyde-3-phosphate dehydrogenase (1/60,000 dilution, AB8245;
Abcam, Cambridge, MA, USA). All immunoblots were developed and quantified using the Odyssey infrared imaging system (Li-Cor Biosystems, Lincoln, NE, USA) using infrared-labeled anti-mouse and anti-rabbit IgG (1/30,000 dilution) secondary antibodies.

\section{Statistical analysis}

All data are given as the mean \pm SEM. Statistical analyses were performed using GraphPad Prism (Prism 5 for Mac OS X). One-way ANOVA for multiple comparisons was used, followed by a parametric $t$ test with Fisher's correction. For paired studies, the Wilcoxon signed rank test was used. Percentage of arrhythmic cells data was analyzed by a $\chi^{2}$ test. A $p$ value of 0.05 or less was taken as statistically significant.
A

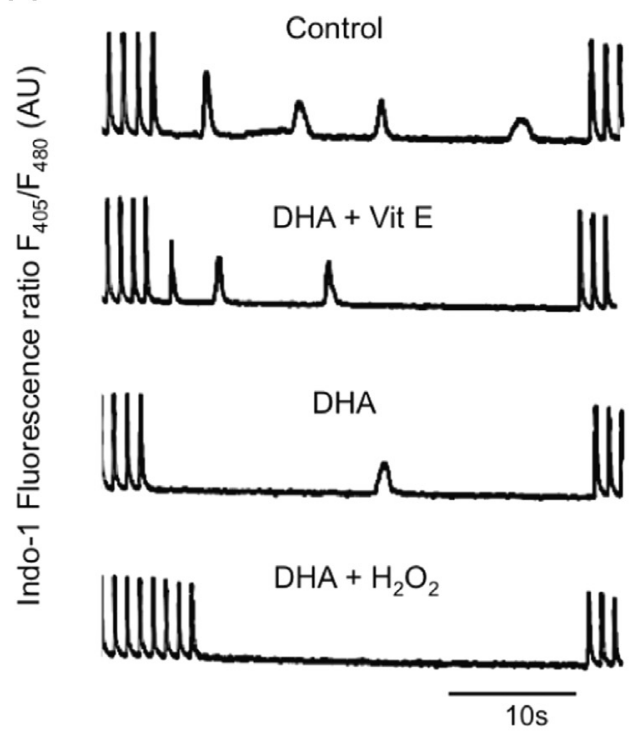

C

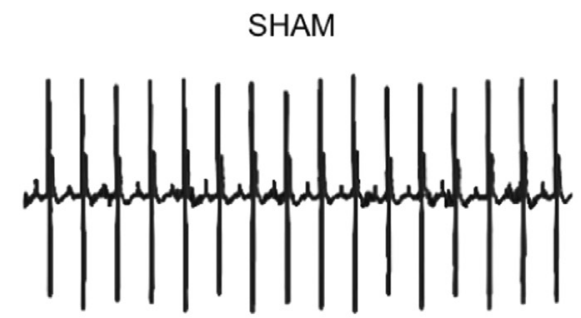

PMI

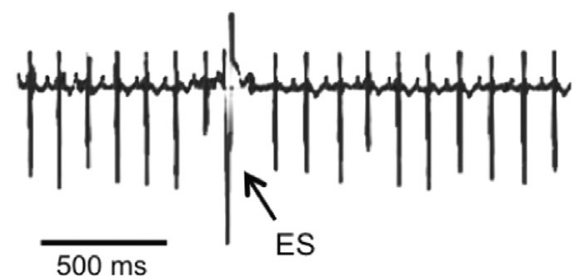

B

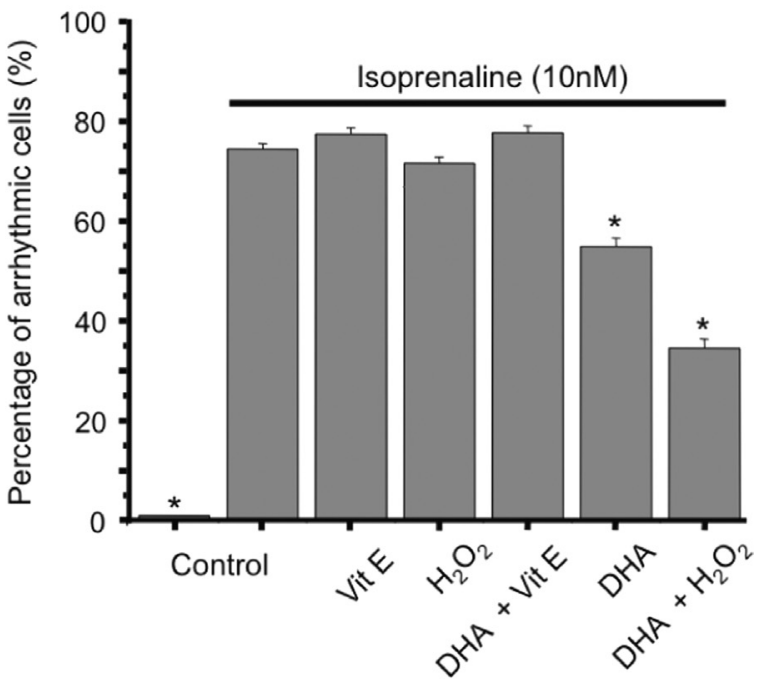

D

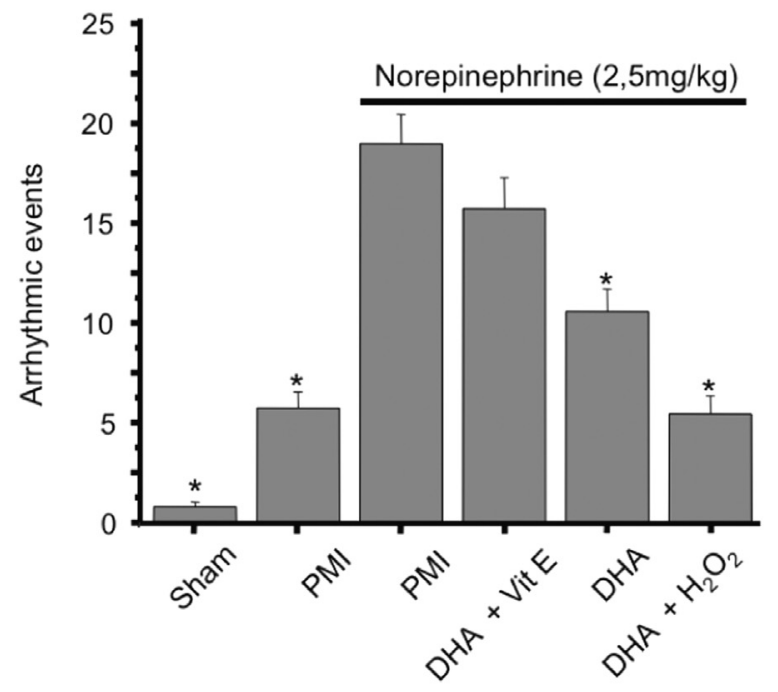

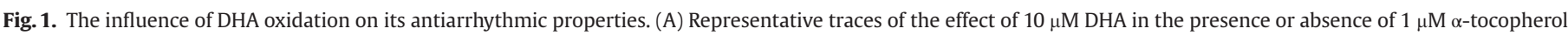

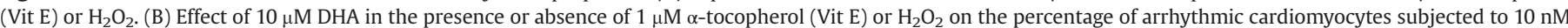

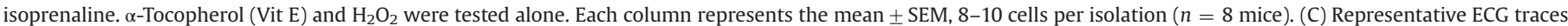

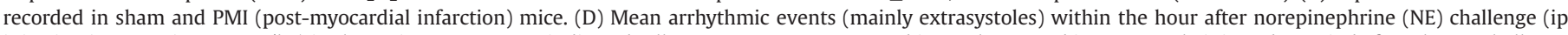

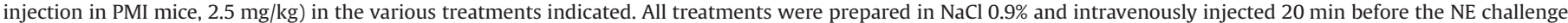
( $n=11$ mice per treatment). ${ }^{*} p<0.05$ vs control. 


\section{Results}

DHA under oxidative stress conditions reduced cardiac arrhythmias

AAP of DHA were evaluated in models of cardiac arrhythmia. Different conditions of oxidative status were obtained by preparing DHA solutions in the presence of an antioxidant, $1 \mu \mathrm{M} \alpha$-tocopherol [27], or a pro-oxidant, $1 \mu \mathrm{M} \mathrm{H} \mathrm{H}_{2} \mathrm{O}_{2}$ [28]. Bathing isolated mouse ventricular cardiomyocytes for $20 \mathrm{~min}$ in DHA prevented arrhythmias, which concurs in part with a previous report [11]. Importantly, AAP of DHA were potentiated by pro-oxidants and conversely prevented in the presence of $\alpha$-tocopherol (Fig. 1A and B). When applied alone, $\mathrm{H}_{2} \mathrm{O}_{2}$ and $\alpha$-tocopherol had no effect (Fig. 1B), which further supports the role of DHA oxidation on AAP.

Additionally, we investigated the efficacy of DHA at reducing the trigger of ventricular extrasystoles (ESs) in a PMI mouse model established by coronary artery ligation and sensitized by NE [29]. PMI mice develop calcium-dependent ESs due to increased diastolic calcium levels in the context of increased ROS production [30]. These arrhythmias are potentiated by a norepinephrine challenge. In this validated model and as described in Table 1, intravenous injection of DHA into the mice reduced ESs by $45 \%$, which further reinforced the AAP of DHA under pro-oxidant conditions (Fig. 1C and D).

\section{$A A P$ are not mediated by enzymatic oxidation of DHA}

Enzymatic oxidation of DHA can develop endogenously [31], like the conditions used in this experimental approach. The AAP of DHA were investigated in cardiomyocytes in the presence of various inhibitors of enzymes that oxidize PUFAs, namely, cyclooxygenase (COX-2), lipoxygenase (LOX), and cytochrome P450 (CYP450). Individually or combined, the inhibitors did not modify the AAP of prooxidized DHA (Fig. 2A). Our observation infers that DHA exerts strong AAP through a nonenzymatic peroxidation process that generates metabolites such as $\mathrm{F}_{4}$-neuroprostanes and not through a typical enzymatic process that involves, for example, resolvins, protectins, and maresins. To further explore the chemical entities needed for the observed AAP, we buffered any hydroperoxyl derivatives potentially formed by our pro-oxidant conditions ( $\mathrm{DHA}+\mathrm{H}_{2} \mathrm{O}_{2}$ ) by a late addition of GPx (Fig. 2B). AAP were still observed under these conditions, indicating these effects are not related to endoperoxide or hydroperoxide metabolites of DHA. In contrast, arrhythmias persisted when GPx was added before DHA $+\mathrm{H}_{2} \mathrm{O}_{2}$, indicating that $\mathrm{H}_{2} \mathrm{O}_{2}$ initiated the formation of the required metabolites of DHA for AAP (Fig. 2B).

Among the $F_{4}$-neuroprostanes, $4(R S)-4-F_{4 t}$-NeuroP had the most active $A A P$

Supplementation of DHA to atherosclerotic $\mathrm{LDLR}^{-1-}$ mice showed that the liver $\mathrm{F}_{4}$-NeuroP concentration is negatively correlated with atherosclerosis risk [17]. The isomer $4(R S)-4-\mathrm{F}_{4 t}-\mathrm{NeuroP}$ is the most abundant $\mathrm{F}_{4}$-NeuroP formed from nonenzymatic DHA peroxidation [14]. In our in vitro experiments, incubation of DHA (10 $\mu \mathrm{M})$ with $\mathrm{H}_{2} \mathrm{O}_{2}(1 \mu \mathrm{M})$ in Tyrode solution for 20 min generated $0.61 \pm 0.08 \mu \mathrm{M} 4$ $(R S)-4-F_{4 t}-$ NeuroP (Fig. $3 \mathrm{~A}$ and B), whereas DHA with Vit E produced no $4(R S)-4-\mathrm{F}_{4 \mathrm{t}}-\mathrm{NeuroP}$ and DHA alone produced trace amounts $(0.03 \pm 0.01 \mu \mathrm{M})$. Furthermore, we recently discovered that levels of $4(R S)-4-\mathrm{F}_{4 \mathrm{t}}-\mathrm{NeuroP}$ and another isomer, $10-\mathrm{F}_{4 \mathrm{t}^{-}}$-neuroprostane $\left(10-\mathrm{F}_{4 \mathrm{t}^{-}}\right.$ NeuroP), are concentrated in brains of preterm pigs [32] and in adult rat brain and heart [33].

From our findings, the high concentration of $4(R S)-4-\mathrm{F}_{4 \mathrm{t}}-\mathrm{NeuroP}$ in the heart indicates a potential bioactive role. We compared the antiarrhythmic effect of $4(R S)-4-\mathrm{F}_{4 \mathrm{t}}-\mathrm{NeuroP}$ with other $\mathrm{F}_{4}$-neuroprostanes (10- $\mathrm{F}_{4 \mathrm{t}}-$ NeuroP, $13-\mathrm{F}_{4 \mathrm{t}}-\mathrm{NeuroP}, 14(R S)-4-\mathrm{F}_{4 \mathrm{t}}-\mathrm{NeuroP}$; Table 2). Of the four $\mathrm{F}_{4}$-neuroprostanes tested, $4(R S)-4 \mathrm{~F}_{4 \mathrm{t}}$-NeuroP is the most potent $\left(\mathrm{IC}_{50} \approx 100 \mathrm{nM}\right.$; Fig. 3C).

Despite the $\mathrm{IC}_{50}$ of $\approx 100 \mathrm{nM}$ for $4(R S)-4-\mathrm{F}_{4 \mathrm{t}}-$ NeuroP, we used the maximum concentration $(1 \mu \mathrm{M})$ to authenticate the AAP in our study. Our in vivo evaluation indicates that the AAP of $1 \mu \mathrm{M} 4(R S)$ 4- $\mathrm{F}_{4 \mathrm{t}}$-NeuroP were comparable with those of the positive control, $1 \mu \mathrm{M}$ carvedilol, which is a referenced antiarrhythmic drug (Fig. 3D). Also, 4(RS)-4-F $4 \mathrm{t}-$ NeuroP inhibited arrhythmias produced by the adenylyl cyclase activator forskolin (Fig. 3E), suggesting that $\beta$-blocking properties are not involved in the AAP of $4(R S)-4-\mathrm{F}_{4 \mathrm{t}^{-}}$ NeuroP. The absence of bradycardia after $4(R S)-4-\mathrm{F}_{4 \mathrm{t}} \mathrm{-NeuroP}$ consolidates this hypothesis (Table 1 ). Further, the AAP of DHA + $\mathrm{H}_{2} \mathrm{O}_{2}$ and $4(R S)-4-\mathrm{F}_{4 \mathrm{t}}-$ NeuroP were similar, suggesting that the AAP of DHA is largely due to the generation of $4(R S)-4-\mathrm{F}_{4 \mathrm{t}}-\mathrm{NeuroP}$ in $\mathrm{DHA}+\mathrm{H}_{2} \mathrm{O}_{2}$.
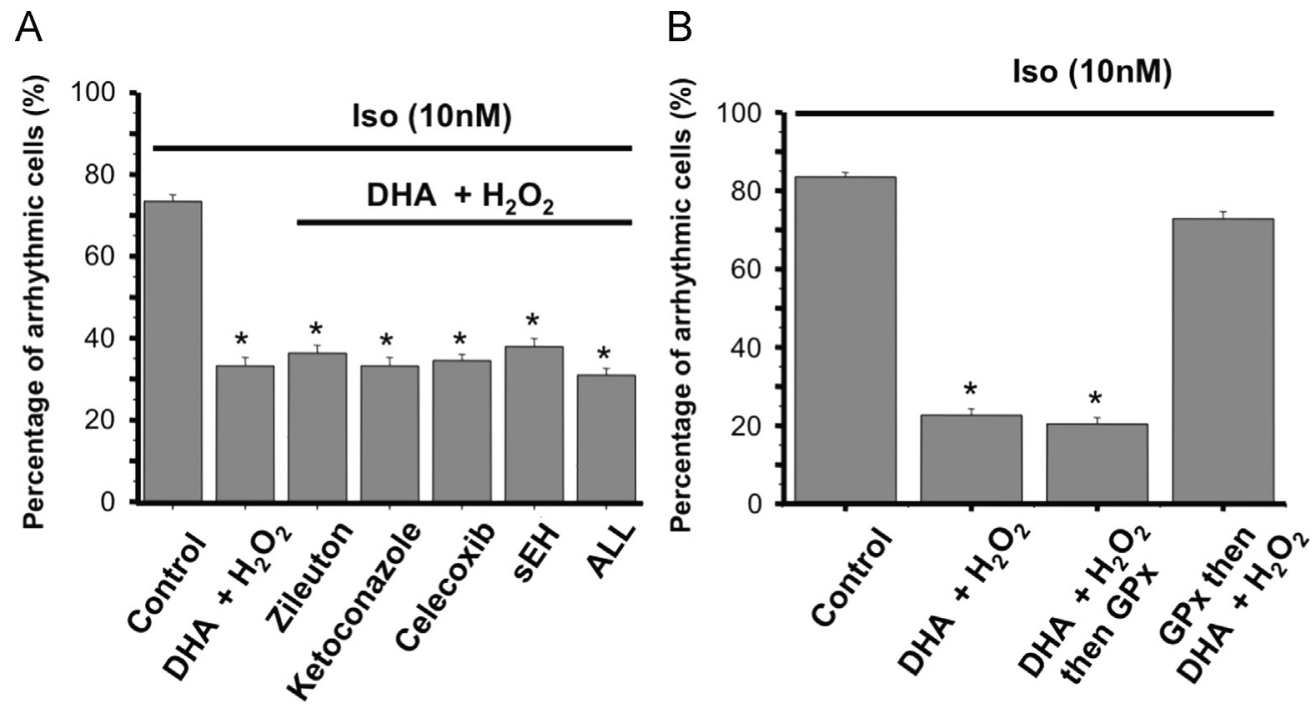

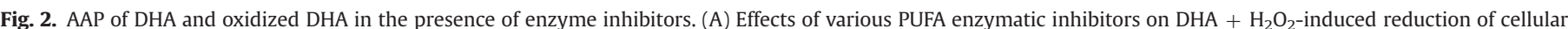

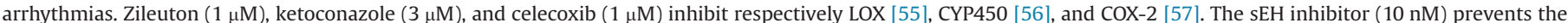

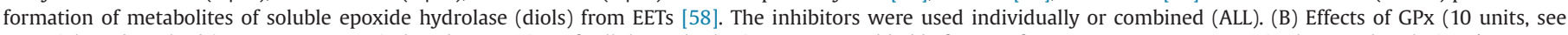

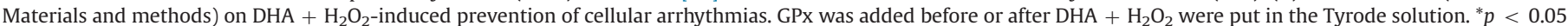
vs control. 
A

$4(R S)-4-\mathrm{F}_{4 \mathrm{t}}-$ neuroprostane

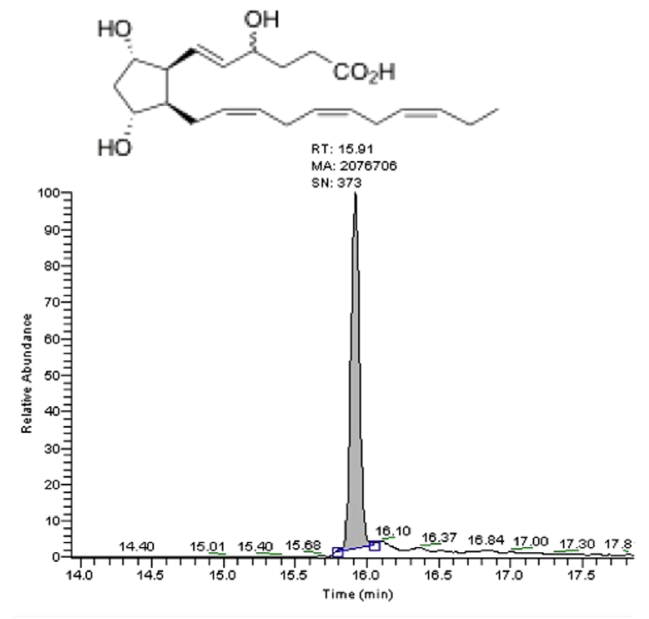

B

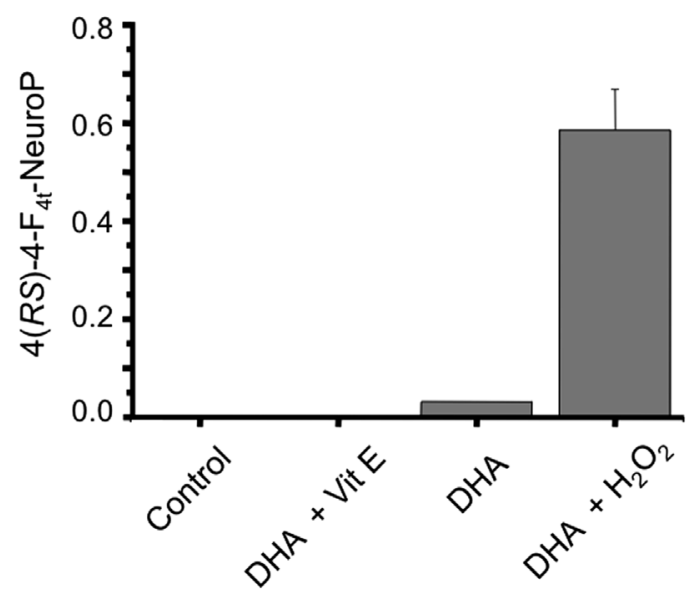

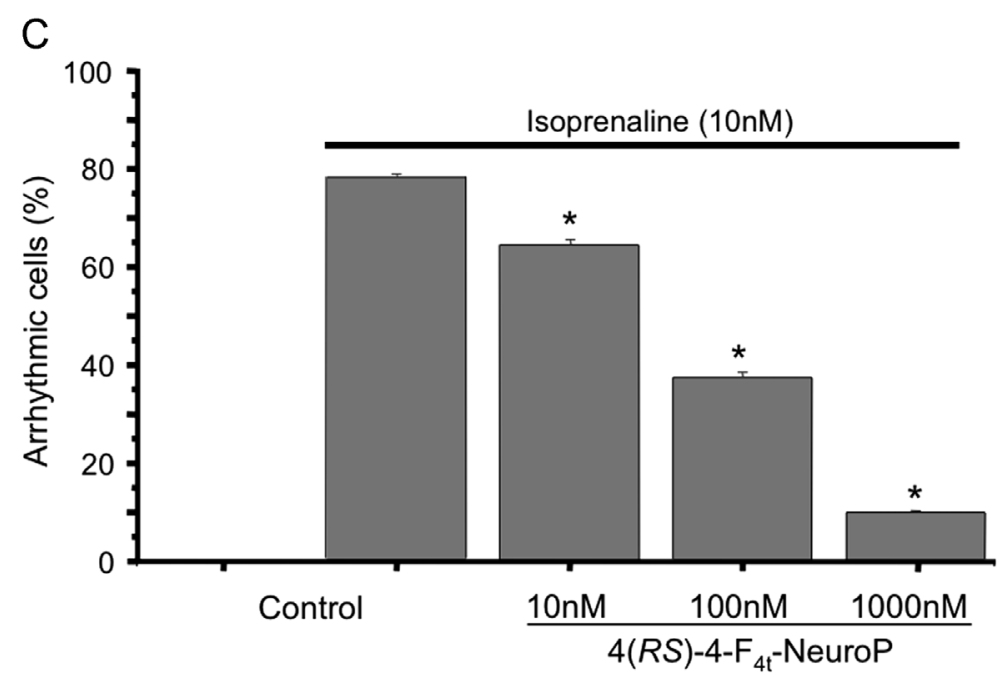

D

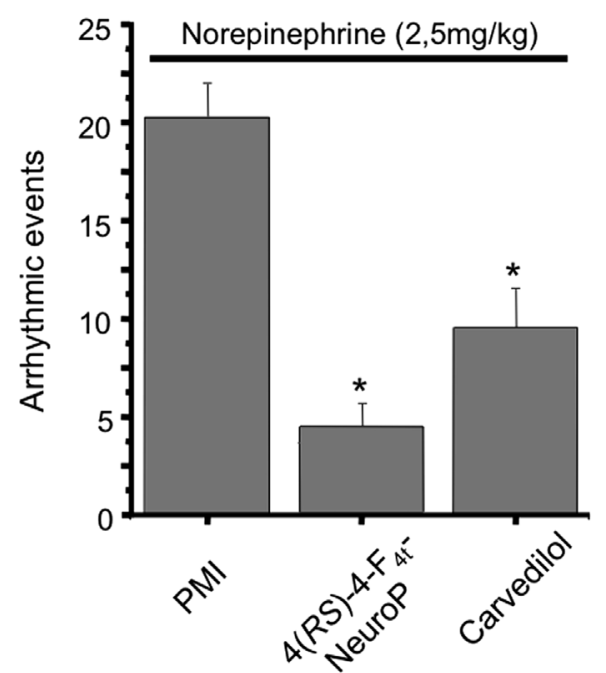

E

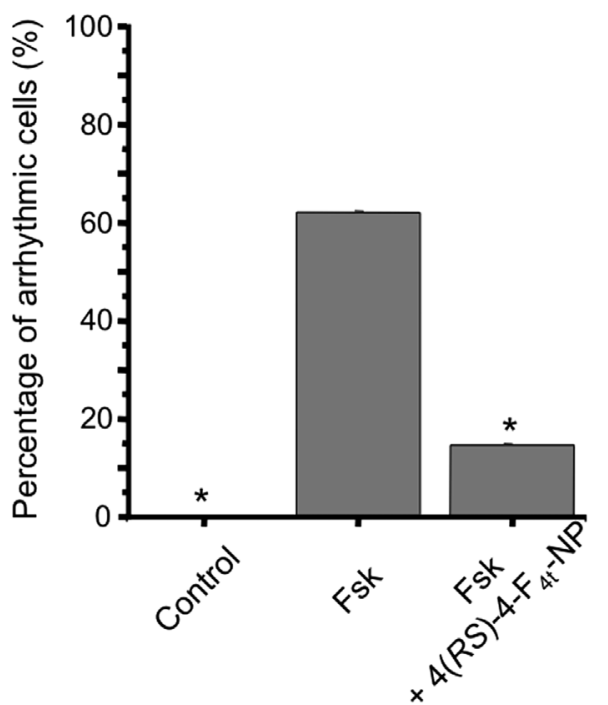

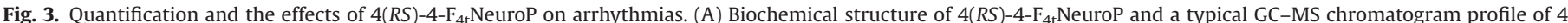

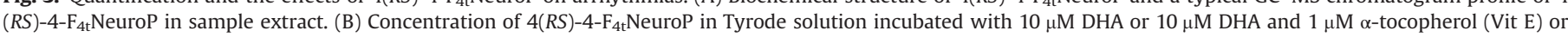

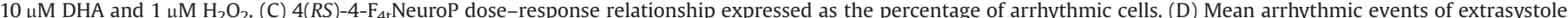

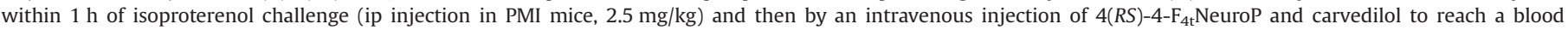
concentration of $1 \mu \mathrm{M}$. (E) Effects of $4(R S)-4-\mathrm{F}_{4 \mathrm{t}}$ NeuroP on $10 \mu \mathrm{M}$ forskolin (Fsk)-induced cellular arrhythmias. ${ }^{*} p<0.05$ vs control or Fsk. 
Table 2

Antiarrhythmic properties of various $\mathrm{F}_{4}$-neuroprostanes on single cardiac ventricular myocytes.

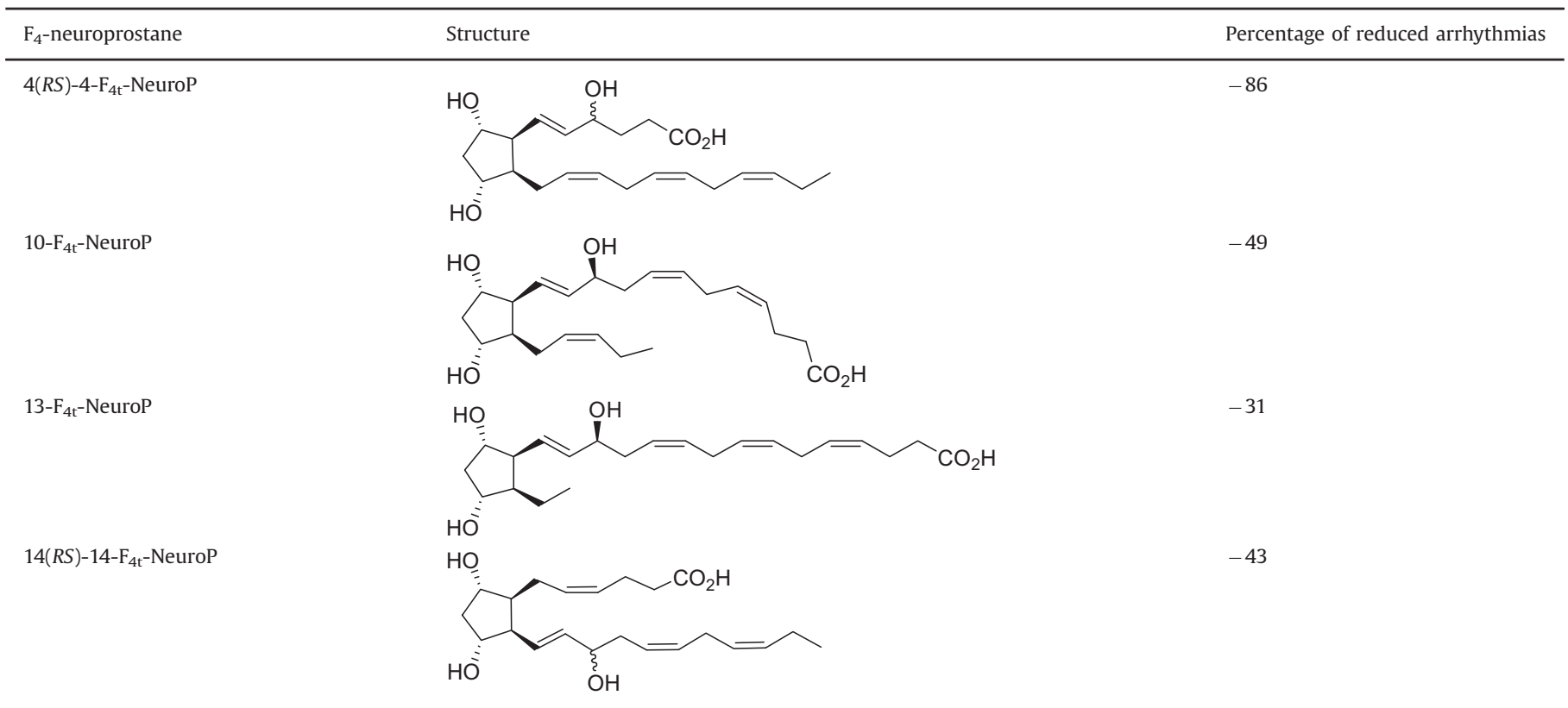

Cardiomyocytes were incubated for $20 \mathrm{~min}$ in the presence of $1 \mu \mathrm{M} \mathrm{F}_{4}$-neuroprostanes before the proarrhythmic protocol (see Materials and methods). Each compound was tested on approximately 30 cells (four or five mice). Results are expressed in percentage as the reduction in the number of arrhythmic cells after the treatment relative to control (no treatment).

A
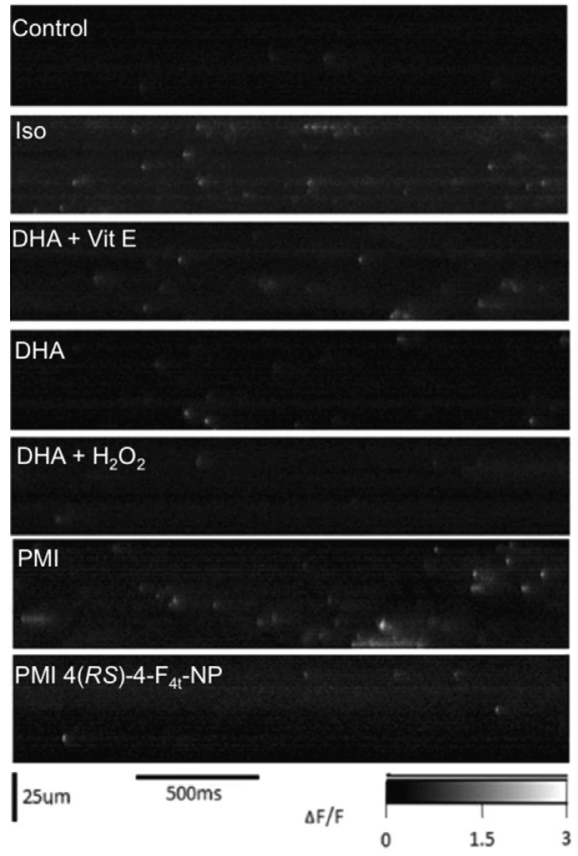

B

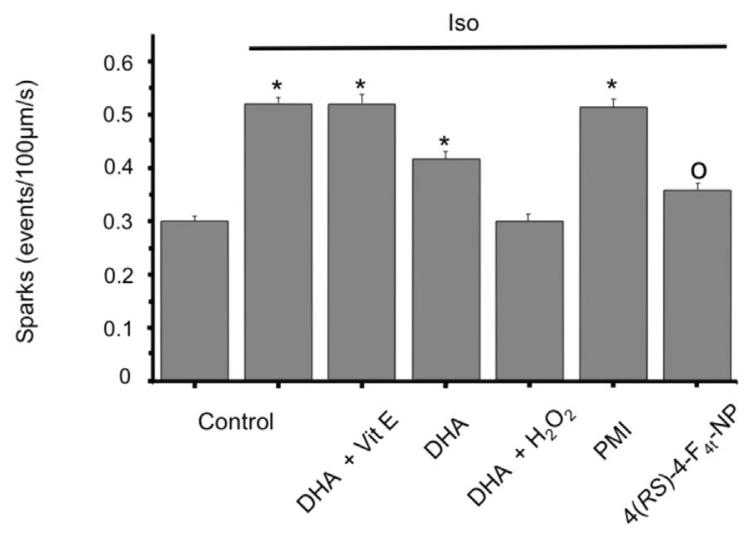

C

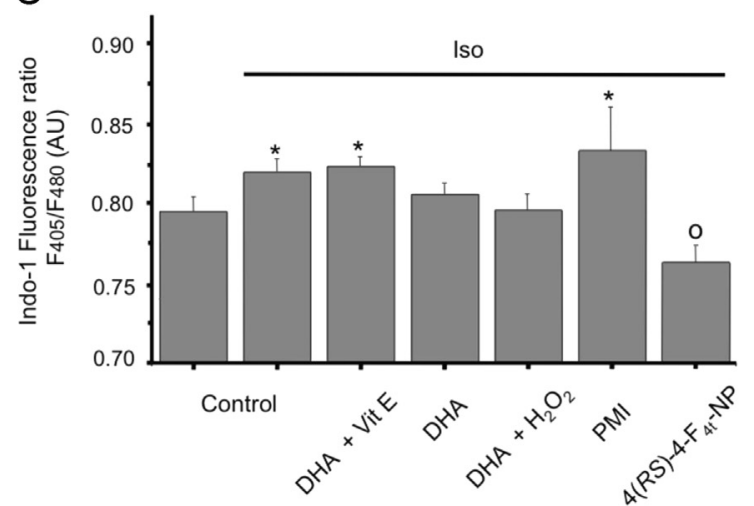

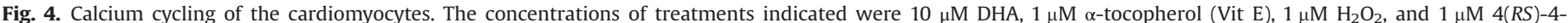

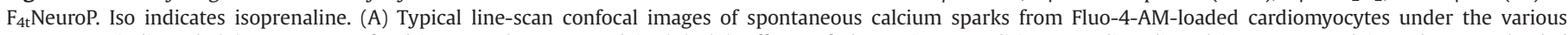

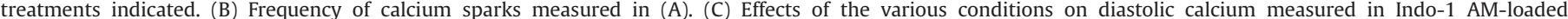
cardiomyocytes (expressed as the ratio of fluorescence at 480 and $405 \mathrm{~nm}$ ). ${ }^{*} p<0.05$ vs control; ${ }^{\circ} p<0.05$ vs PMI. 
A

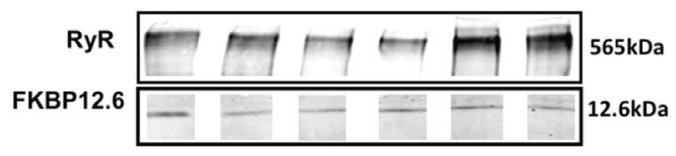

C

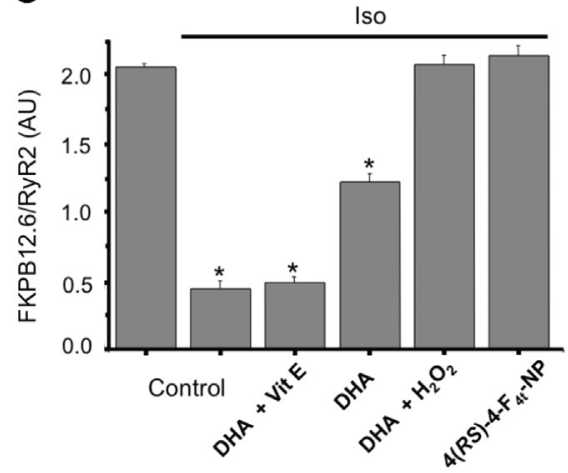

$E$

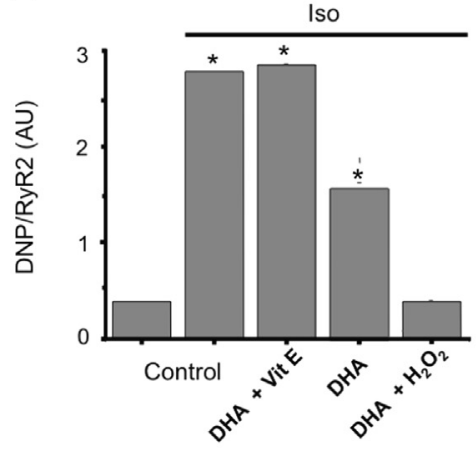

B

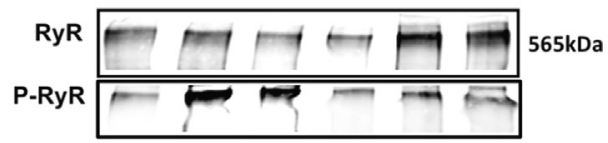

$\mathrm{D}$

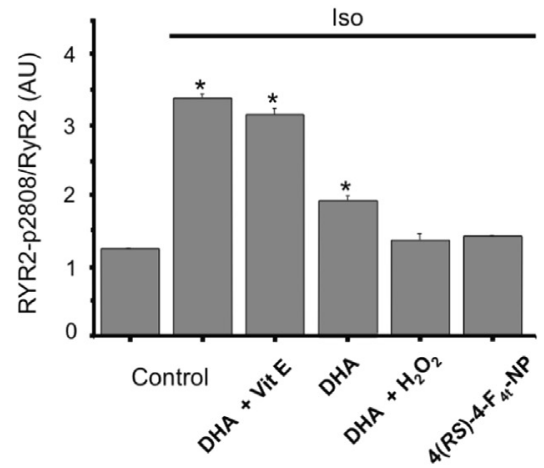

$\mathrm{F}$

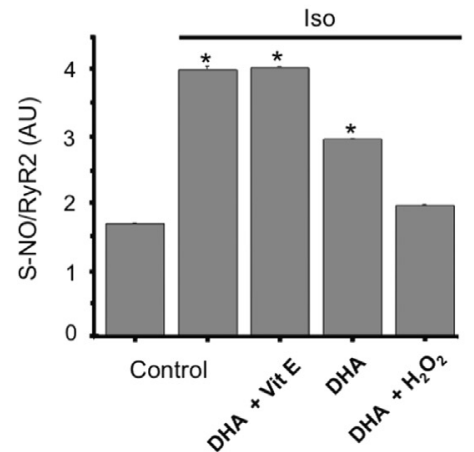

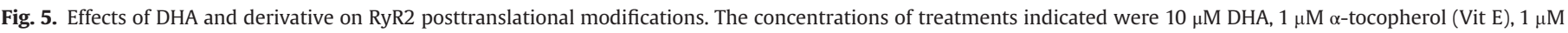

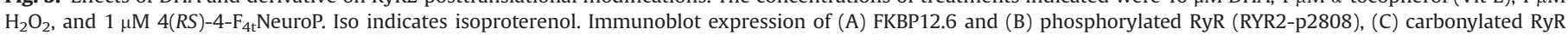
(DNP), and (D) S-nitrosylated RyR (S-NO) against RyR2 is shown after Iso treatment of cardiomyocytes.

\section{4(RS)-4-F 4 -NeuroP prevents RyR2 dysfunction}

In our experimental models, the arrhythmias prevented by $4(R S)-$ 4- $\mathrm{F}_{4 \mathrm{t}}$-NeuroP are mainly due to ESs. The mechanisms of triggering ESs include alterations in $\mathrm{Ca}^{2+}$ homeostasis that are potentiated by catecholamines; the two phenomena are observed after myocardial infarction [34]. The $\mathrm{Ca}^{2+}$ signaling alteration could be associated with a leaky RyR2 [35-37]. As a consequence, cytosolic $\mathrm{Ca}^{2+}$ levels in diastole rise and promote ESs [38]. We thus evaluated the leaky behavior of RyR2 by measuring the frequency of spontaneous $\mathrm{Ca}^{2+}$ sparks by confocal microscopy [39] and the resting cytosolic $\mathrm{Ca}^{2+}$ concentration by epifluorescence. In our model, $\mathrm{Ca}^{2+}$ spark event frequency was increased by isoprenaline (Fig. $4 \mathrm{~A}$ and $\mathrm{B}$ ). This increase was partially prevented by DHA as also shown in previous reports $[40,41]$. Interestingly, the effects of DHA on $\mathrm{Ca}^{2+}$ spark frequency were blunted by $\alpha$-tocopherol and enhanced by $\mathrm{H}_{2} \mathrm{O}_{2}$. PMI cardiomyocytes also exhibited an increased frequency of $\mathrm{Ca}^{2+}$ sparks that was significantly reduced by $4(R S)-4-\mathrm{F}_{4 \mathrm{t}}-\mathrm{NeuroP}$. The changes in the spark frequency followed changes in resting $\mathrm{Ca}^{2+}$ concentration (Fig. 4C).

At the molecular level, posttranslational modifications of RyR2 may account for their leaky behavior [35-37]. We quantified RyR2 carbonylation, S-nitrosylation, and phosphorylation and the degree of association of RyR2 with FKBP12.6 on the arrhythmic cardiomyocytes after $10 \mathrm{nM}$ isoproterenol (Iso) treatment with or without $10 \mu \mathrm{M}$ DHA, $10 \mu \mathrm{M}$ DHA $+1 \mu \mathrm{M}$ Vit E, or $10 \mu \mathrm{M}$ DHA $+1 \mu \mathrm{M} \mathrm{H}_{2} \mathrm{O}_{2}$ (Fig. 5). Iso challenge promotes dissociation of FKBP12.6 from the RyR2 macromolecular complex as previously reported and accounts for the abnormal SR $\mathrm{Ca}^{2+}$ leak [35] (Fig. 5A). Iso also promotes RyR2 carbonylation, S-nitrosylation, and phosphorylation on serine 2808 (Fig. 5B-D). These effects were prevented by DHA and more so by DHA $+\mathrm{H}_{2} \mathrm{O}_{2}$ compared to Iso and DHA + Vit E. This is supported by the lack of FKBP12.6 dissociation from the RyR2 complex of DHA or DHA $+\mathrm{H}_{2} \mathrm{O}_{2}$ treatment compared to Iso and DHA + Vit E (Fig. 5A). Additionally, our observations indicate that oxidation of DHA is necessary to prevent RyR2 modification as no effect was found in the presence of Vit E, an antioxidant. To verify that the involvement of such an effect is due to a nonenzymatic oxidized lipid product of DHA, we repeated the evaluation on the arrhythmic cardiomyocytes with 4 $(R S)-4-\mathrm{F}_{4 \mathrm{t}}-$ NeuroP (Fig. 5A and B). The prevention of RyR2 phosphorylation and dissociation of FKBP12.6 of NeuroP was comparable to that of DHA $+\mathrm{H}_{2} \mathrm{O}_{2}$. This strongly supports that the effects of oxidized DHA and $4(R S)-4-\mathrm{F}_{4 \mathrm{t}}-\mathrm{NeuroP}$ in correcting SR $\mathrm{Ca}^{2+}$ leak, normalizing diastolic $\mathrm{Ca}^{2+}$ level, and preventing ES triggering result from the counteraction of RyR2 posttranslational modifications and RyR2 dysfunction.

\section{Discussion}

In the present study, we clearly demonstrated that oxidized DHA possesses potent AAP in cellulo and in vivo and that unmodified DHA 
per se was inactive. This effect is not mediated by enzymatic lipid peroxidation but instead by neuroprostanes, the stable end products of the nonenzymatic lipid peroxidation of DHA, particularly $4(R S)-4$ $\mathrm{F}_{4 \mathrm{t}}$-NeuroP. This metabolite displayed a unique and unprecedented mode of action among the family of lipid mediators and among any known endogenous biomolecule, as it stabilized RyR2 and maintained this complex closed during diastole.

This discovery bridges the missing relationship between cardiac ischemic events and the AAP of DHA. Indeed, in cardiac ischemic diseases and myocardial infarction there is a burst of ROS [42] that can be involved in the generation of arrhythmias, the origin of SCD [43]. Such an abrupt imbalance in the oxidative status can oxidize proteins [44], nucleic acids [45], and lipids [46]. These highly reactive compounds play a pivotal role in the pathogenesis of postischemic injury that progresses to SCD $[47,48]$. Classically, there is a consensus that overproduction of ROS is mainly deleterious and does not play a role in normal physiology. For example, it has been shown that an isoketal, $\mathrm{E}_{2^{-}}$ IsoK, originating from the oxidation of arachidonic acid can produce adducts with the sodium channel protein $\mathrm{Na}_{\vee} 1.5$, perturbing its activity in a proarrhythmic way [47]. However, the possibility that nonenzymatic oxygenated metabolites of $\omega 3$ PUFAs can exert countereffects has been underinvestigated.

We have previously reported that DHA needs to be oxidized to influence ionic channel activities [12] and it is agreed by others that such effects on ionic channels contribute to the AAP of DHA [49]. We here demonstrated that the AAP of DHA are dependent on the oxidative status of the environment and that nonenzymatic autoxidation of DHA was a prerequisite of AAP. Our assays pinpointed neuroprostane metabolites as potential metabolites with APP properties. The main isomer, $4(R S)-4-\mathrm{F}_{4 \mathrm{t}}-\mathrm{NeuroP}$, showed potent dose-dependent AAP in cellulo and also in vivo in PMI mice.

At the cellular level, the mechanism of action is unlikely to be due to a $\beta$-blocker effect, but the AAP can instead be explained by a rycallike effect; in particular, stabilization of the RyR2 complex with FKBP12.6 [50]. This effect was strongly supported by both oxidized DHA and $4(R S)-4-\mathrm{F}_{4 \mathrm{t}}-\mathrm{NeuroP}$ in correcting SR $\mathrm{Ca}^{2+}$ leak and normalizing diastolic $\mathrm{Ca}^{2+}$ levels and from the prevention of the dissociation of FKBP12.6 from RyR2. Although we cannot exclude a direct effect of $4(R S)-4-\mathrm{F}_{4 \mathrm{t}}$-NeuroP on RyR2, in contrast to rycal effects, we also observed that both oxidized DHA and $4(R S)-4-\mathrm{F}_{4 \mathrm{t}}-$ NeuroP prevent RyR2 hyperactive S-nitrosylation, oxidation, and phosphorylation, suggesting an upstream mechanism rather than a direct effect on RyR2 as previously reported [37]. Altogether we showed that 4(RS)-4$\mathrm{F}_{4 \mathrm{t}}$-NeuroP is capable of preventing ES-triggering effects from the prevention of RyR2 posttranslational modifications and RyR2 dysfunction by normalizing RyR2 activity in diastole and thus calcium homeostasis.

Emulsion of $\omega 3$ PUFAs injected intravenously has been shown to be antiarrhythmic in a canine model of myocardial infarction [7], and similar effects on sustained ventricular tachycardia have been observed in humans $[20,51]$. The use of an in vivo ischemic model to monitor the triggering of ventricular ES clearly confirmed our hypothesis that DHA has to be transformed autoxidatively into neuroprostane for rapid inhibition of arrhythmias.

The prerequisite for DHA oxidation to elicit any AAP could explain the lack of elucidation of the beneficial effects of $\omega 3$ PUFAs other than in ischemic cardiovascular diseases [2,52,53]. After initial reports establishing that $\omega 3$ PUFAs have cardioprotective properties, the beneficial effects were extended to many if not all cardiovascular problems, even those that are not ischemic [53,54]. This mind-set could be a drawback for the proper development of therapeutic targets in cardiac ischemia and part of the difficulty in justifying its valuable impact in cardioprotection. Overall, the mechanism of action we describe here can explain the favorable impact of $\omega 3$ PUFAs in chronic diseases, implicating RyR2 dysfunction when an unbalanced oxidative status is present.

\section{Conclusion}

From this work, we conclude that the oxidation of DHA to 4(RS)-4$\mathrm{F}_{4 \mathrm{t}}$ NeuroP is necessary to prevent ischemia-induced arrhythmias. We propose that under oxidative stress conditions such as ischemic diseases, nonenzymatic oxygenated metabolites of DHA formed by peroxidation of cardiac membrane lipids, notably $4(R S)-4-\mathrm{F}_{4 \mathrm{t}} \mathrm{NeuroP}$, are responsible for the AAP of DHA by countering the cellular stress by ROS. Importantly, it appears that nonenzymatically oxygenated metabolites of $\omega 3$ PUFAs can communicate and exert a physiological role. This highlights potential beneficial effects of increased ROS production dependent on the cellular environment.

\section{Acknowledgments}

A part of this work was financially supported by the Universite de Montpellier (Grants BQR-2008 and 2011), the Centre National de la Recherche Scientifique (CNRS) for PEPII INSB-INC, and the Fondation pour la Recherche Médicale (FRM) (DCM20111223047). We are grateful to Valérie Bultel-Poncé and Alexandre Guy for their assistance in synthesizing the $4(R S)-4-\mathrm{F}_{4 \mathrm{t}}-\mathrm{NeuroP}$ and to Valérie Scheuerman and Patrice Bideaux for performing biochemistry and preparing the PMI mice, respectively.

\section{References}

[1] Bang, H. O.; Dyerberg, J.; Hjøorne, N. The composition of food consumed by Greenland Eskimos. Acta Med. Scand 200:69-73; 1976.

[2] Burr, M. L.; Fehily, A. M.; Gilbert, J. F.; Rogers, S.; Holliday, R. M.; Sweetnam, P. M.; Elwood, P. C.; Deadman, N. M. Effects of changes in fat, fish, and fibre intakes on death and myocardial reinfarction: diet and reinfarction trial (DART). Lancet 2:757-761; 1989.

[3] Siscovick, D. S.; Raghunathan, T. E.; King, I.; Weinmann, S.; Wicklund, K. G.; Albright, J.; Bovbjerg, V.; Arbogast, P.; Smith, H.; Kushi, L. H. Dietary intake and cell membrane levels of long-chain n-3 polyunsaturated fatty acids and the risk of primary cardiac arrest. JAMA 274:1363-1367; 1995

[4] Albert, C. M.; Campos, H.; Stampfer, M. J.; Ridker, P. M.; Manson, J. E.; Willett, W. C.; Ma, J. Blood levels of long-chain n-3 fatty acids and the risk of sudden death. N. Engl. J. Med. 346:1113-1118; 2002.

[5] Mozaffarian, D.; Lemaitre, R. N.; Kuller, L. H.; Burke, G. L.; Tracy, R. P.; Siscovick, D. S. Cardiovascular Health Study. Cardiac benefits of fish consumption may depend on the type of fish meal consumed: the Cardiovascular Health Study. Circulation 107:1372-1377; 2003.

[6] Dietary supplementation with $n-3$ polyunsaturated fatty acids and vitamin E after myocardial infarction: results of the GISSI-Prevenzione trial. Gruppo Italiano per lo Studio della Sopravvivenza nell'Infarto miocardico. Lancet 354: 447-455; 1999

[7] Billman, G. E.; Kang, J. X.; Leaf, A. Prevention of sudden cardiac death by dietary pure omega-3 polyunsaturated fatty acids in dogs. Circulation 99:2452-2457; 1999

[8] Billman, G. E.; Hallaq, H.; Leaf, A. Prevention of ischemia-induced ventricular fibrillation by omega 3 fatty acids. Proc. Natl. Acad. Sci. USA 91:4427-4430; 1994.

[9] McLennan, P. L.; Bridle, T. M.; Abeywardena, M. Y.; Charnock, J. S. Dietary lipid modulation of ventricular fibrillation threshold in the marmoset monkey. Am. Heart J. 123:1555-1561: 1992.

[10] Mozaffarian, D.; Prineas, R. J.; Stein, P. K.; Siscovick, D. S. Dietary fish and n-3 fatty acid intake and cardiac electrocardiographic parameters in humans. J. Am. Coll. Cardiol. 48:478-484; 2006.

[11] Leaf, A.; Kang, J. X.; Xiao, Y. -F. Fish oil fatty acids as cardiovascular drugs. Curr. Vasc. Pharmacol 6:1-12; 2008.

[12] Judé, S.; Bedut, S.; Roger, S.; Pinault, M.; Champeroux, P.; White, E.; Le Guennec, J. -Y. Peroxidation of docosahexaenoic acid is responsible for its effects on I TO and I SS in rat ventricular myocytes. Br. J. Pharmacol. 139:816-822; 2003.

[13] Zhao, Z.; Wen, H.; Fefelova, N.; Allen, C.; Guillaume, N.; Xiao, D.; Huang, C. Zang, W.: Gwathmey, J. K.; Xie, L. -H. Docosahexaenoic acid reduces the incidence of early afterdepolarizations caused by oxidative stress in rabbit ventricular myocytes. Front. Physiol 3:252; 2012.

[14] Roberts, L. J.; Montine, T. J.; Markesbery, W. R.; Tapper, A. R.; Hardy, P.; Chemtob, S.; Dettbarn, W. D.; Morrow, J. D. Formation of isoprostane-like 
compounds (neuroprostanes) in vivo from docosahexaenoic acid. J. Biol. Chem. 273:13605-13612; 1998.

[15] Roberts, L. J.; Fessel, J. P.; Davies, S. S. The biochemistry of the isoprostane, neuroprostane, and isofuran pathways of lipid peroxidation. Brain Pathol. 15:143-148; 2005.

[16] Seet, R. C. S.; Lee, C. -Y. J.; Chan, B. P. L.; Sharma, V. K.; Teoh, H. -L. Venketasubramanian, N.; Lim, E. C. H.; Chong, W. -L.; Looi, W. -F.; Huang, S. -H.; Ong, B. K. C.; Halliwell, B. Oxidative damage in ischemic stroke revealed using multiple biomarkers. Stroke J. Cereb. Circ. 42:2326-2329; 2011.

[17] Gladine, C.; Newman, J. W.; Durand, T.; Pedersen, T. L.; Galano, J. -M.; Demougeot, C.; Berdeaux, O.; Pujos-Guillot, E.; Mazur, A.; Comte, B. Lipid profiling following intake of the omega 3 fatty acid DHA identifies the peroxidized metabolites F4-neuroprostanes as the best predictors of atherosclerosis prevention. PLoS One 9:e89393; 2014.

[18] Thireau, J.; Karam, S.; Fauconnier, J.; Roberge, S.; Cassan, C.; Cazorla, O.; Aimond, F.; Lacampagne, A.; Babuty, D.; Richard, S. Functional evidence for an active role of B-type natriuretic peptide in cardiac remodelling and proarrhythmogenicity. Cardiovasc. Res. 95:59-68; 2012.

[19] Podrid, P. J.; Fuchs, T.; Candinas, R. Role of the sympathetic nervous system in the genesis of ventricular arrhythmia. Circulation 82:I103-I113; 1990.

[20] Den Ruijter, H. M.; Berecki, G.; Verkerk, A. O.; Bakker, D.; Baartscheer, A.; Schumacher, C. A.; Belterman, C. N. W.; de Jonge, N.; Fiolet, J. W. T.; Brouwer, I. A.; Coronel, R. Acute administration of fish oil inhibits triggered activity in isolated myocytes from rabbits and patients with heart failure. Circulation 117:536-544; 2008.

[21] Oger, C.; Brinkmann, Y.; Bouazzaoui, S.; Durand, T.; Galano, J. -M. Stereocontrolled access to isoprostanes via a bicyclo[3.3.0]octene framework. Org. Lett. 10:5087-5090; 2008.

[22] Oger, C.; Bultel-Poncé, V.; Guy, A.; Balas, L.; Rossi, J. -C.; Durand, T.; Galano, J. -M. The handy use of Brown's P2-Ni catalyst for a skipped diyne deuteration: application to the synthesis of a $\left[\mathrm{D}_{4}\right]$-labeled $\mathrm{F}_{4 \mathrm{t}}$-neuroprostane. Chem. Eur. J 16:13976-13980; 2010.

[23] Guy, A.; Oger, C.; Heppekausen, J.; Signorini, C.; De Felice, C.; Fürstner, A.; Durand, T.; Galano, J. -M. Oxygenated metabolites of n-3 polyunsaturated fatty acids as potential oxidative stress biomarkers: total synthesis of 8- $\mathrm{F}_{3 \mathrm{t}}$-IsoP, 10 $\mathrm{F}_{4 \mathrm{t}}-$ NeuroP and $\left[\mathrm{D}_{4}\right]-10-\mathrm{F}_{4 \mathrm{t}}-$ NeuroP. Chem. Eur. J 20:6374-6380; 2014.

[24] Taber, D. F.; Reddy, P. G.; Arneson, K. O. A potential route to neuroprostanes and isoprostanes: preparation of the four enantiomerically pure diastereomers of 13-F4t-neuroP. J. Org. Chem. 73:3467-3474; 2008.

[25] Mas, E.; Michel, F.; Guy, A.; Bultel, V.; Falquet, Y.; Chardon, P.; Rossi, J. -C.; Cristol, J. P.; Durand, T. Quantification of urinary F2-isoprostanes with 4(RS)F4t-neuroprostane as an internal standard using gas chromatography-mass spectrometry: application to polytraumatized patients. J. Chromatogr. B Anal. Technol. Biomed. Life. Sci. 872:133-140; 2008.

[26] Berecki, G.; Den Ruijter, H. M.; Verkerk, A. O.; Schumacher, C. A.; Baartscheer A.; Bakker, D.; Boukens, B. J.; van Ginneken, A. C. G.; Fiolet, J. W. T.; Opthof, T.; Coronel, R. Dietary fish oil reduces the incidence of triggered arrhythmias in pig ventricular myocytes. Heart Rhythm 4:1452-1460; 2007.

[27] Burton, G. W.; Ingold, K. U. Vitamin E as an in vitro and in vivo antioxidant. Ann. N. Y. Acad. Sci. 570:7-22; 1989.

[28] Janero, D. R.; Hreniuk, D.; Sharif, H. M. Hydrogen peroxide-induced oxidative stress to the mammalian heart-muscle cell (cardiomyocyte): lethal peroxidative membrane injury. J. Cell. Physiol. 149:347-364; 1991.

[29] Tarnavski, O.; McMullen, J. R.; Schinke, M.; Nie, Q.; Kong, S.; Izumo, S. Mouse cardiac surgery: comprehensive techniques for the generation of mouse models of human diseases and their application for genomic studies. Physiol. Genomics 16:349-360; 2004.

[30] Hori, M.; Nishida, K. Oxidative stress and left ventricular remodelling after myocardial infarction. Cardiovasc. Res. 81:457-464; 2009.

[31] Wang, R.; Chai, Q.; Lu, T.; Lee, H. -C. Activation of vascular BK channels by docosahexaenoic acid is dependent on cytochrome P450 epoxygenase activity. Cardiovasc. Res. 90:344-352; 2011.

[32] De La Torre, A.; Lee, Y. Y.; Oger, C.; Sangild, P. T.; Durand, T.; Lee, J. C. -Y.; Galano, J. -M. Synthesis, discovery, and quantitation of dihomo-isofurans: biomarkers for in vivo adrenic acid peroxidation. Angew. Chem. Int. Ed. Engl. 53:6249-6252; 2014

[33] De la Torre, A.; Lee, Y. Y.; Mazzoni, A.; Guy, A.; Bultel-Poncé, V.; Durand, T.; Oger, C.; Lee, J. C. -Y.; Galano, J. -M. Total syntheses and in vivo quantitation of novel neurofuran and dihomo-isofuran derived from docosahexaenoic acid and adrenic acid. Chemistry 21:2442-2446; 2015.

[34] Sankaranarayanan, R.; Venetucci, L. Are the anti-arrhythmic effects of omega3 fatty acids due to modulation of myocardial calcium handling? Front. Physiol 3:373; 2012

[35] Marx, S. O.; Reiken, S.; Hisamatsu, Y.; Jayaraman, T.; Burkhoff, D.; Rosemblit, N.; Marks, A. R. PKA phosphorylation dissociates FKBP12.6 from the calcium release channel (ryanodine receptor): defective regulation in failing hearts. Cell 101:365-376; 2000

[36] Fauconnier, J.; Thireau, J.; Reiken, S.; Cassan, C.; Richard, S.; Matecki, S.; Marks, A. R.; Lacampagne, A. Leaky RyR2 trigger ventricular arrhythmias in Duchenne muscular dystrophy. Proc. Natl. Acad. Sci. USA 107:1559-1564; 2010.

[37] Fauconnier, J.; Meli, A. C.; Thireau, J.; Roberge, S.; Shan, J.; Sassi, Y.; Reiken, S. R.; Rauzier, J. -M.; Marchand, A.; Chauvier, D.; Cassan, C.; Crozier, C.; Bideaux, P.; Lompré, A. -M.; Jacotot, E.; Marks, A. R.; Lacampagne, A. Ryanodine receptor leak mediated by caspase- 8 activation leads to left ventricular injury after myocardial ischemia-reperfusion. Proc. Natl. Acad. Sci. USA 108:13258-13263; 2011.

[38] Xie, L. -H.; Weiss, J. N. Arrhythmogenic consequences of intracellular calcium waves. Am. J. Physiol. Heart Circ. Physiol 297:H997-H1002; 2009.

[39] Cheng, H.; Lederer, W. J.; Cannell, M. B. Calcium sparks: elementary events underlying excitation-contraction coupling in heart muscle. Science 262:740-744; 1993.

[40] Negretti, N.; Perez, M. R.; Walker, D.; O'Neill, S. C. Inhibition of sarcoplasmic reticulum function by polyunsaturated fatty acids in intact, isolated myocytes from rat ventricular muscle. J. Physiol. 523:367-375; 2000.

[41] O'Neill, S. C.; Perez, M. R.; Hammond, K. E.; Sheader, E. A.; Negretti, N. Direct and indirect modulation of rat cardiac sarcoplasmic reticulum function by n-3 polyunsaturated fatty acids. J. Physiol. 538:179-184; 2002.

[42] Bolli, R. Causative role of oxyradicals in myocardial stunning: a proven hypothesis. A brief review of the evidence demonstrating a major role of reactive oxygen species in several forms of postischemic dysfunction. Basic Res. Cardiol. 93:156-162; 1998.

[43] Downey, J. M. Free radicals and their involvement during long-term myocardial ischemia and reperfusion. Annu. Rev. Physiol. 52:487-504; 1990.

[44] Davies, K. J. Protein damage and degradation by oxygen radicals. I. Genera aspects. J. Biol. Chem. 262:9895-9901; 1987.

[45] Dizdaroglu, M. Oxidative damage to DNA in mammalian chromatin. Mutat Res. 275:331-342; 1992.

[46] Burton, K. P.; Morris, A. C.; Massey, K. D.; Buja, L. M.; Hagler, H. K. Free radicals alter ionic calcium levels and membrane phospholipids in cultured rat ventricular myocytes. J. Mol. Cell. Cardiol. 22:1035-1047; 1990.

[47] Fukuda, K.; Davies, S. S.; Nakajima, T.; Ong, B. -H.; Kupershmidt, S.; Fessel, J.; Amarnath, V.; Anderson, M. E.; Boyden, P. A.; Viswanathan, P. C.; Roberts, L. J.; Balser, J. R. Oxidative mediated lipid peroxidation recapitulates proarrhythmic effects on cardiac sodium channels. Circ. Res. 97:1262-1269; 2005.

[48] Jeong, E. -M.; Liu, M.; Sturdy, M.; Gao, G.; Varghese, S. T.; Sovari, A. A.; Dudley, S. C. Metabolic stress, reactive oxygen species, and arrhythmia. J. Mol. Cell. Cardiol. 52:454-463; 2012.

[49] Leaf, A.; Xiao, Y. F.; Kang, J. X.; Billman, G. E. Prevention of sudden cardiac death by n-3 polyunsaturated fatty acids. Pharmacol. Ther 98:355-377; 2003.

[50] Andersson, D. C.; Marks, A. R. Fixing ryanodine receptor Ca leak-a nove therapeutic strategy for contractile failure in heart and skeletal muscle. Drug Discovery Today Dis. Mech. 7:e151-e157; 2010.

[51] Schrepf, R.; Limmert, T.; Claus Weber, P.; Theisen, K.; Sellmayer, A. Immediate effects of n-3 fatty acid infusion on the induction of sustained ventricular tachycardia. Lancet 363:1441-1442; 2004.

[52] Marchioli, R.; Barzi, F.; Bomba, E.; Chieffo, C.; Di Gregorio, D.; Di Mascio, R. Franzosi, M. G.; Geraci, E.; Levantesi, G.; Maggioni, A. P.; Mantini, L.; Marfisi, R M.; Mastrogiuseppe, G.; Mininni, N.; Nicolosi, G. L.; Santini, M.; Schweiger, C.; Tavazzi, L.; Tognoni, G.; Tucci, C.; Valagussa, F. GISSI-Prevenzione Investigators. Early protection against sudden death by $n-3$ polyunsaturated fatty acids after myocardial infarction: time-course analysis of the results of the Gruppo Italiano per lo Studio della Sopravvivenza nell'Infarto Miocardico (GISSI)Prevenzione. Circulation 105:1897-1903; 2002.

[53] De Lorgeril, M.; Salen, P.; Defaye, P.; Rabaeus, M. Recent findings on the health effects of omega-3 fatty acids and statins, and their interactions: do statins inhibit omega-3? BMC Med. 11:5; 2013.

[54] Von Schacky, C. Omega-3 index and sudden cardiac death. Nutrients 2:375-388; 2010.

[55] Lu, P.; Schrag, M. L.; Slaughter, D. E.; Raab, C. E.; Shou, M.; Rodrigues, A. D. Mechanism-based inhibition of human liver microsomal cytochrome P450 $1 \mathrm{~A} 2$ by zileuton, a 5-lipoxygenase inhibitor. Drug Metab. Dispos. Biol. Fate Chem 31:1352-1360; 2003.

[56] Peri, K. G.; Almazan, G.; Varma, D. R.; Chemtob, S. A role for protein kinase C alpha in stimulation of prostaglandin $\mathrm{G} / \mathrm{H}$ synthase-2 transcription by 14,15 epoxyeicosatrienoic acid. Biochem. Biophys. Res. Commun. 244:96-101; 1998.

[57] Brueggemann, L. I.; Mackie, A. R.; Mani, B. K.; Cribbs, L. L.; Byron, K. L. Differential effects of selective cyclooxygenase-2 inhibitors on vascular smooth muscle ion channels may account for differences in cardiovascular risk profiles. Mol. Pharmacol. 76:1053-1061; 2009.

[58] Imig, J. D.; Hammock, B. D. Soluble epoxide hydrolase as a therapeutic target for cardiovascular diseases. Nat. Rev. Drug Discovery 8:794-805; 2009. 